\title{
Quantification of C4d deposition and hepatitis C virus RNA in tissue in cases of graft rejection and hepatitis $\mathrm{C}$ recurrence after liver transplantation
}

\author{
Alice Tung Wan Song ${ }^{1,2} /{ }^{+}$, Evandro Sobroza de Mello ${ }^{3}$, Venâncio Avancini Ferreira Alves ${ }^{3}$, \\ Norma de Paula Cavalheiro", Carlos Eduardo Melo ${ }^{4}$, Patricia Rodrigues Bonazzi", \\ Fatima Mitiko Tengan ${ }^{4,5}$, Maristela Pinheiro Freire ${ }^{6}$, Antonio Alci Barone ${ }^{4}$, \\ Luiz Augusto Carneiro D'Albuquerque ${ }^{1,2}$, Edson Abdala ${ }^{1,4,5}$
}

\author{
1Divisão de Transplante de Fígado e Órgãos do Aparelho Digestivo ${ }^{2}$ Laboratório de Transplante de Fígado - LIM 37 \\ ${ }^{3}$ Departamento de Patologia ${ }^{4}$ Laboratório de Hepatites Virais - LIM $47{ }^{5}$ Divisão de Clínica de Moléstias Infecciosas e Parasitárias \\ ${ }^{6}$ Subcomissão de Infecção Hospitalar, Hospital das Clínicas, Universidade de São Paulo, SP, Brasil
}

\begin{abstract}
Histology is the gold standard for diagnosing acute rejection and hepatitis C recurrence after liver transplantation. However, differential diagnosis between the two can be difficult. We evaluated the role of C4d staining and quantification of hepatitis C virus (HCV) RNA levels in liver tissue. This was a retrospective study of 98 liver biopsy samples divided into four groups by histological diagnosis: acute rejection in patients undergoing liver transplant for hepatitis $C$ (RejHCV+), HCV recurrence in patients undergoing liver transplant for hepatitis C (HCVTx+), acute rejection in patients undergoing liver transplant for reasons other than hepatitis $C$ and chronic hepatitis $C$ not transplanted (HCVTX-). All samples were submitted for immunohistochemical staining for C4d and HCV RNA quantification. Immunoexpression of C4d was observed in the portal vessels and was highest in the HCVTx-group. There was no difference in C4d expression between the RejHCV+ and HCVTx+ groups. However, tissue HCV RNA levels were higher in the HCVTx+ group samples than in the RejHCV+ group samples. Additionally, there was a significant correlation between tissue and serum levels of HCV RNA. The quantification of HCV RNA in liver tissue might prove to be an efficient diagnostic test for the recurrence of HCV infection.
\end{abstract}

Key words: complement - humoral - PCR - tissue - immunohistochemistry

Advanced liver disease caused by hepatitis $\mathrm{C}$ virus $(\mathrm{HCV})$ infection is the leading indication for liver transplantation worldwide (Saab \& Wang 2003, Roche \& Samuel 2007). The post-transplant detection of HCV RNA in the serum or graft is extremely common, occurring in more than $95 \%$ of cases (Berenguer 2002, Roche \& Samuel 2007). In more than half of those cases, infection recurs within the first year after transplantation. In transplant recipients, the disease is particularly aggressive, with rapid progression of fibrosis (Berenguer 2002). During post-transplant follow up, elevated liver enzymes warrant liver biopsies for accurate diagnosis and treatment and it can be difficult to differentiate between acute rejection and recurrence of hepatitis C. Although histological evaluation is the gold-standard method for distinguishing between the two entities, there have been reports of misdiagnosis because of overlapping morphological features (McCaughan \& Zekry 2002, Leung et al. 2003, Regev et al. 2004).

doi: 10.1590/0074-02760140192

Financial support: FAPESP (2008/10124-0)

+ Corresponding author: alicetwsong@gmail.com

Received 2 June 2014

Accepted 1 December 2014
Following activation of the complement system, the $\mathrm{C} 4 \mathrm{~d}$ fragment forms a covalent bond with tissues and $\mathrm{C} 4 \mathrm{~d}$ immunostaining has been widely used to demonstrate antibody-mediated rejection of organ transplants (Michaels et al. 2003). There is evidence that humoral mechanisms are involved in the pathogenesis of acute rejection in liver transplant recipients (Takakura et al. 1999, Krukemeyer et al. 2004, Sawada et al. 2005, Bu et al. 2006). Recent studies have correlated concurrent donorspecific human leukocyte antigen (HLA) antibody detection with the histological features of this form of rejection and C4d immunostaining (Bellamy et al. 2007, Sakashita et al. 2007, Aguilera et al. 2011, Kozlowski et al. 2011, 2012, Musat et al. 2011, Lunz et al. 2012). In some studies in liver transplantation, $\mathrm{C} 4 \mathrm{~d}$ staining has been shown to be useful as a complementary method for discriminating between graft rejection and the recurrence of hepatitis C (Jain et al. 2006, Lorho et al. 2006, Schmeding et al. 2006, 2010). Studies of correlations between serum HCV RNA levels and the recurrence of hepatitis $\mathrm{C}$ have indicated that the determination of serum HCV RNA can also be used to discriminate between these two diagnoses (Fragulidis et al. 1998, Aardema et al. 1999, Gottschlich et al. 2001, D'Errico-Grigioni et al. 2008).

In the present study, we aimed to evaluate $\mathrm{C} 4 \mathrm{~d}$ immunostaining and quantification of HCV RNA in tissue, including their utility in differentiating hepatitis $\mathrm{C}$ recurrence from acute rejection in cases of acute rejection in patients with and without $\mathrm{HCV}$ infection, $\mathrm{HCV}$ recur- 
rence and chronic hepatitis $\mathrm{C}$ in the non-transplant setting. We also attempted to determine whether $\mathrm{C} 4 \mathrm{~d}$ deposition correlated with epidemiological, clinical and histological features of acute rejection and hepatitis $\mathrm{C}$ recurrence, as well as whether the level of HCV RNA in tissue correlated with the histological features of chronic hepatitis.

\section{PATIENTS, MATERIALS AND METHODS}

Study design - This study was performed using liver biopsies from patients who had undergone liver transplantation or from outpatients with chronic hepatitis C. All of the biopsies evaluated had been performed between 1998-2011 at the University of São Paulo School of Medicine (FMUSP) Clinics Hospital. A local ethical committee approved the study.

Patients - The specimens were initially obtained from a list of histological diagnoses and reviewed by two pathologists with expertise in the field who were blinded to the clinical diagnoses. We selected biopsy samples that met the following eligibility criteria: obtained from biopsies performed within the first year after the transplant (when applicable); had only one sample from each patient and contained six or more portal tracts, with four or more centrilobular hepatic veins. We excluded biopsy samples obtained from patients with hepatitis B, autoimmune hepatitis, primary biliary cirrhosis, primary sclerosing cholangitis or storage diseases for all groups. We also excluded samples in which signs of rejection and hepatitis $\mathrm{C}$ recurrence were both found, as they were not related to this study's objective.

On the basis of the histological diagnosis, we divided the biopsy samples into four groups: acute rejection in recipients of liver transplants performed because of HCV-related cirrhosis (RejHCV+), recurrence of hepatitis $\mathrm{C}$ in recipients of liver transplants performed because of $\mathrm{HCV}$-related cirrhosis (HCVTx + ), acute rejection in recipients of liver transplants performed for reasons other than HCV infection (RejHCV-) and chronic hepatitis $\mathrm{C}$ patients in a non-transplant setting (HCVTx-).

On the basis of those criteria, we selected 98 formalin-fixed, paraffin-embedded liver tissue samples for inclusion in the study.

Recurrence of hepatitis $\mathrm{C}$ was defined as the posttransplant presence of HCV RNA in serum and chronic portal inflammation, with or without portal lymphoid aggregates, together with necroinflammatory and ductular-type interface activity of varying severity (Demetris 2009). For the grading and staging of chronic hepatitis, the modified Ishak classification was used (Ishak et al. 1995). Acute rejection was defined as inflammation of the graft, primarily affecting the interlobular bile ducts and vascular endothelia, including the portal veins and hepatic venules, with or without involvement of the hepatic artery and its branches (Banff schema for grading liver allograft rejection: an international consensus document 1997). For the grading and staging of acute rejection, the Banff criteria were used (Banff schema for grading liver allograft rejection: an international consensus document 1997).

Clinical and laboratory data - Patient charts were reviewed and the following data were collected (when ap- plicable): age, gender, time from transplantation to biopsy (arbitrarily divided into intervals), living or deceased donor, donor age, main diagnosis before transplantation, pre-transplant or pre-biopsy use of interferon (IFN), total ischemia time, pre-transplant or pre-biopsy serum $\mathrm{HCV}$ RNA, immunosuppressive drugs and HCV genotype.

Immunohistochemical staining for $C 4 d$ - All of the specimens were subjected to immunohistochemical staining for $\mathrm{C} 4 \mathrm{~d}$ and the same two pathologists performed the quantitative grading for all the specimens. All of the fields were analysed and positivity was defined as clear-cut immunostaining of endothelial cell membranes of each vascular component, specifically portal veins, sinusoids and (centrilobular) hepatic veins. Due to the current debate about the specificity of $\mathrm{C} 4 \mathrm{~d}$ immunoreactivity of the hepatic artery, C4d staining in the hepatic artery was not considered indicative of positivity, nor was stromal staining for $\mathrm{C} 4 \mathrm{~d}$.

In brief, $3-\mu \mathrm{m}$ tissue sections were deparaffinised, unmasked and stained with a commercially available polyclonal antibody against C4d (BI-RC4D, 1:50; Biomedica, Austria). Heat-induced epitope retrieval was optimised with the EDTA/TRIS buffer, $\mathrm{pH}$ 8.0, for 40 $\min$ in a steamer. Amplification was performed using the polymer-peroxidase complex (Novolink Max Polymer; Novocastra Laboratories, UK). As the chromogen for the peroxidase reaction, we used 3,3'-diaminobenzidine (Dako, Denmark). Counter-staining was performed with Harris haematoxylin and the endogenous peroxidase was blocked using hydrogen peroxide. The positive controls consisted of kidney biopsy samples with known antibodymediated rejection and the negative controls consisted of samples stained without the primary antibody.

$H C V$ RNA quantification - Specimens from the Re$\mathrm{jHCV}+$, HCVTx + and HCVTx- groups were subjected to HCV RNA quantification by polymerase chain reaction (PCR). The HCV RNA extraction was performed on 10$\mu \mathrm{m}$ samples of formalin-fixed, paraffin-embedded tissue sections using a commercially available kit (High Pure RNA Paraffin Kit; Roche Diagnostics GmbH, Germany), as per the standardised protocol. Microtubes containing the eluted RNA were stored at $-80^{\circ} \mathrm{C}$ until RNA amplification.

For real-time amplification, we used a commercial kit $\left(\mathrm{COBAS}^{\circledR}{ }^{\mathrm{T}} \mathrm{TaqMan}^{\circledR} \mathrm{HCV}\right.$; Roche Diagnostics $\mathrm{GmbH}$ ) according to the standardised protocol. The reaction was performed in a Cobas Taqman 48 analyser (Roche Molecular Systems, USA) and was analysed using the Amplilink software v.3.2 (Roche Molecular Systems). The lower and upper limits of detection were $25 \mathrm{IU} \mathrm{mL}^{-1}$ and $3.91 \times 10^{8} \mathrm{IU} \mathrm{mL}^{-1}$, respectively.

Negative and positive controls consisted of specimens from patients who had undergone transplantation for primary biliary cirrhosis and of known HCV RNApositive samples, respectively. All reactions were performed only once.

Statistical analysis - The sample size was calculated on the basis of the prevalence of C4d positivity, as reported in a previous study (Schmeding et al. 2006), which was $67 \%$ for acute rejection and $12 \%$ for hepa- 
titis $\mathrm{C}$ recurrence. Using two-sample tests for proportion comparisons with a significance level of 0.05 and a power of 0.8 , we obtained prevalence values of 0.55 , $0.6,0.65,0.7$ and 0.75 for acute rejection and of $0.05,0.1$, 0.15 and 0.2 for hepatitis $\mathrm{C}$ recurrence; all possible combinations were compared. It was determined that there should be at least 28 cases in each of the study groups (RejHCV+ and $\left.\mathrm{HCVTx}^{+}\right)$and at least 22 cases in each of the control groups (RejHCV- and HCVTx-).

Quantitative variables were described using measures of central tendency and dispersion and were compared using the Kruskal-Wallis test, followed by Dunn's multiple comparison test or analysis of variance, followed by Tukey's multiple comparison test. Qualitative variables were described using absolute and relative frequencies and compared using chi-square tests or likelihood ratios. For ordinal qualitative variables, we used the MannWhitney $U$ or Kruskal-Wallis test. Variables showing statistical significance in the univariate analysis were included in logistic regressions for multivariate analysis. Spearman's correlation coefficient was calculated for both diagnostic tests with qualitative and ordinal variables. For variables showing statistical significance, a linear regression model was created for multivariate analysis. For the PCR analysis of HCV RNA, we constructed a receiver operating characteristic (ROC) curve. The statistical analysis was performed using the Statistical Package for the Social Sciences v.15.0 for Windows (SPSS Inc, USA) and the level of significance was set at $\mathrm{p}<0.05$ for all tests.

Ethics - The procedures followed were in accordance with the ethical standards of the responsible institutional committee on human experimentation and with the Helsinki Declaration of 1975, as revised in 1983.

\section{RESULTS}

Demographic, clinical and laboratory data - Ninetyeight biopsy samples were selected: 28 cases in the Re$\mathrm{jHCV}+$ group, 25 cases in the HCVTx + group, 20 cases in the RejHCV- group and 25 cases in the HCVTx- group. The baseline characteristics of each group are shown in Tables I, II. There were significant differences among the groups in terms of the mean patient age at biopsy (p $=0.005$ ): in the multiple comparison test, a statistically significant difference was found between the HCVTx+ and RejHCV- groups (54 years vs. 44.5 years, $p=0.02$ ), as well as between the HCVTx+ and HCVTx- groups (54 years vs. 45.5 years, $p=0.03$ ).

TABLE I

Qualitative baseline characteristics of all $\operatorname{cases}^{a}$

\begin{tabular}{|c|c|c|c|c|c|c|c|}
\hline \multirow[b]{2}{*}{ Variable } & \multirow[b]{2}{*}{ Category } & \multicolumn{4}{|c|}{$\begin{array}{l}\text { Group } \\
\mathrm{n}(\%)\end{array}$} & \multirow[b]{2}{*}{ Total } & \multirow[b]{2}{*}{$\mathrm{p}$} \\
\hline & & RejHCV+ & HCVTx+ & RejHCV- & HCVTx- & & \\
\hline \multirow[t]{2}{*}{ Gender } & Male & $17(60.7)$ & $18(72)$ & $9(45)$ & $12(48)$ & $56(57.1)$ & \multirow{2}{*}{$\mathrm{NS}^{b}$} \\
\hline & Female & $11(39.3)$ & $7(28)$ & $11(55)$ & $13(52)$ & $42(42.9)$ & \\
\hline \multirow[t]{3}{*}{ Donor type } & Deceased & $22(91.7)$ & $22(88)$ & $20(100)$ & - & $64(92.8)$ & \multirow{3}{*}{$\mathrm{NS}^{c}$} \\
\hline & Living & $0(0)$ & $2(8)$ & $0(0)$ & - & $2(2.9)$ & \\
\hline & Domino & $2(8.3)$ & $1(4)$ & $0(0)$ & - & $3(4.3)$ & \\
\hline \multirow[t]{2}{*}{ Previous IFN use } & No & $6(27.3)$ & $10(40)$ & - & $19(82.6)$ & $35(50)$ & \multirow{2}{*}{$<0.001^{b}$} \\
\hline & Yes & $16(72.7)$ & $15(60)$ & - & $4(17.4)$ & $35(50)$ & \\
\hline \multirow[t]{3}{*}{ HCV genotype } & 1 & $13(59.1)$ & $17(68)$ & - & $14(66.7)$ & $44(64.7)$ & \multirow{3}{*}{$\mathrm{NS}^{c}$} \\
\hline & 2 & $1(4.5)$ & $0(0)$ & - & $0(0)$ & $1(1.5)$ & \\
\hline & 3 & $8(36.4)$ & $8(32)$ & - & $7(33.3)$ & $23(33.8)$ & \\
\hline \multirow[t]{2}{*}{ Use of MMF or MPA } & No & $20(83.3)$ & $18(72)$ & $17(85)$ & - & $55(79.7)$ & \multirow{2}{*}{$\mathrm{NS}^{c}$} \\
\hline & Yes & $4(16.7)$ & $7(28)$ & $3(15)$ & - & $14(20.3)$ & \\
\hline \multirow[t]{2}{*}{ Year of biopsy } & $1998-2006$ & $15(53.6)$ & $7(28)$ & $8(40)$ & $19(76)$ & $49(50)$ & \multirow{2}{*}{$0.006^{b}$} \\
\hline & $2007-2011$ & $13(46.4)$ & $18(72)$ & $12(60)$ & $6(24)$ & $49(50)$ & \\
\hline
\end{tabular}

$a$ : numbers discrepancies are due to missing data (patient charts unavailable); $b$ : chi-square test; $c$ : likelihood ratio test; HCV: hepatitis C virus; HCVTx-: chronic hepatitis C in patients in a non-transplant setting; HCVTx $+:$ hepatitis $C$ recurrence in patients undergoing liver transplant for hepatitis C; IFN: interferon; MMF: mycophenolate mofetil; MPA: mycophenolic acid; NS: nonsignificant; RejHCV-: acute rejection in patients undergoing liver transplant for reasons other than hepatitis C; RejHCV+: acute rejection in patients undergoing liver transplant for hepatitis $\mathrm{C}$. 
TABLE II

Quantitative baseline characteristics of the cases by group

\begin{tabular}{lcccc}
\hline Variable & Group & $\mathrm{n}$ & Mean (range) & $\mathrm{p}$ \\
\hline Age (years) & RejHCV+ & 28 & $52.04(32-67)$ & $0.005^{a}$ \\
& HCVTx+ & 25 & $54.00(25-69)$ & \\
& RejHCV- & 20 & $44.45(21-68)$ & \\
& HCVTx- & 25 & $45.52(22-62)$ & \\
Time from & RejHCV+ & 28 & $18.29(4-95)$ & $<0.001^{b}$ \\
transplantation & HCVTx+ & 25 & $205.52(41-374)$ & \\
to biopsy (days) & RejHCV- & 20 & $41.35(4-276)$ & \\
& RejHCV+ & 23 & $44.96(22-69)$ & $0.021^{a}$ \\
Donor age (years) & HCVTx+ & 23 & $51.78(16-73)$ & \\
& RejHCV- & 20 & $40.20(19-59)$ & \\
Total ischemia & RejHCV+ & 24 & $507.25(186-822)$ & $0.572^{b}$ \\
time (min) & HCVTx+ & 25 & $458.20(133-640)$ & \\
& RejHCV- & 20 & $483.95(297-753)$ &
\end{tabular}

$a$ : ANOVA; $b$ : Kruskal-Wallis test; HCVTx-: chronic hepatitis $\mathrm{C}$ in patients in a non-transplant setting; $\mathrm{HCVTx}+$ : hepatitis $\mathrm{C}$ recurrence in patients undergoing liver transplant for hepatitis $\mathrm{C}$; RejHCV-: acute rejection in patients undergoing liver transplant for reasons other than hepatitis $\mathrm{C}$; RejHCV+: acute rejection in patients undergoing liver transplant for hepatitis $\mathrm{C}$.

The mean time from transplantation to biopsy was longer in the HCVTx+ group (205 days) than in the Re$\mathrm{jHCV}+$ and RejHCV- groups (18 days and 45 days, respectively, $\mathrm{p}<0.001$ for both). Donor age differed only between the HCVTx+ and RejHCV- groups ( $p=0.02)$. When used, immunosuppression therapy consisted of the administration of tacrolimus and prednisone, with or without mycophenolate mofetil; no differences in immunosuppression were observed between the groups. IFN use was more common in the RejHCV + and $\mathrm{HCVTx}^{+}$ groups than in the HCVTx- group $(\mathrm{p}<0.001$ and $\mathrm{p}=$ 0.004 , respectively).

According to the Banff scores, acute rejection in the $\mathrm{RejHCV}+$ and RejHCV- groups, collectively, was mild in 15 cases $(31.3 \%)$, moderate in $23(47.9 \%)$ and severe in 10 (20.8\%), with no differences between the two groups.

The Ishak staging results for the patients with chronic hepatitis demonstrated that there were more cases of advanced-stage fibrosis, portal inflammation and periportal inflammation in the HCVTx- group than in the HCVTx + group $(p<0.001, p=0.004$ and $p=0.04$, respectively). Parenchymal inflammation was comparable between the two groups ( $p=0.37$ for confluent necrosis and $\mathrm{p}=0.64$ for focal lytic necrosis).

C4d immunostaining - As seen in Table III, C4d deposition was observed more often in the portal compartment (68.4\%) than in the sinusoidal and centrilobular compartments $(8.2 \%$ and $10.2 \%$, respectively). The $\mathrm{C} 4 \mathrm{~d}$ deposition observed in the study samples is shown in Figure.
TABLE III

Proportion of $\mathrm{C} 4 \mathrm{~d}$ immunostaining positivity in all groups by hepatic compartment

\begin{tabular}{lccc}
\hline Group & $\begin{array}{c}\text { Portal } \\
\mathrm{n} / \mathrm{N}(\%)\end{array}$ & $\begin{array}{c}\text { Sinusoidal } \\
\mathrm{n} / \mathrm{N}(\%)\end{array}$ & $\begin{array}{c}\text { Centrilobular } \\
\mathrm{n} / \mathrm{N}(\%)\end{array}$ \\
\hline RejHCV+ & $15 / 28(53.5)$ & $3 / 28(10.7)$ & $3 / 28(10.7)$ \\
HCVTx + & $13 / 25(52)$ & $0 / 25(0)$ & $0 / 25(0)$ \\
RejHCV- & $12 / 20(60)$ & $1 / 20(5)$ & $5 / 20(25)$ \\
HCVTx- & $23 / 25(92)$ & $4 / 25(1.6)$ & $2 / 25(8)$ \\
$\mathrm{p}$ & 0.009 & $\mathrm{NS}$ & $\mathrm{NS}$
\end{tabular}

HCVTx-: chronic hepatitis $\mathrm{C}$ in patients in a non-transplant setting; HCVTx+: hepatitis $\mathrm{C}$ recurrence in patients undergoing liver transplant for hepatitis C; NS: non-significant; RejHCV-: acute rejection in patients undergoing liver transplant for reasons other than hepatitis $\mathrm{C}$; RejHCV+: acute rejection in patients undergoing liver transplant for hepatitis $\mathrm{C}$.

Table IV shows the quantification of $\mathrm{C} 4 \mathrm{~d}$ deposition in the groups. In multiple comparisons, the HCVTxgroup presented the greatest deposition ( $\mathrm{p}=0.003$ vs. the $\mathrm{RejHCV}+$ group, $\mathrm{p}<0.001$ vs. the $\mathrm{HCVTx}^{+}$group and $p=0.019$ vs. the RejHCV- group)

We found that portal immunostaining for $\mathrm{C} 4 \mathrm{~d}$ correlated significantly with continuous and categorical variables: total ischemia time (negative correlation, $r=$ $-0.244, \mathrm{p}=0.043$ ), portal fibrosis (positive correlation, $r$ $=0.571, \mathrm{p}<0.001$ ), portal inflammation (positive correlation, $r=0.356, \mathrm{p}=0.011$ ) and periportal inflammation (positive correlation, $r=0.336, \mathrm{p}=0.017$ ). In the logistic regression model for the multivariate analysis, portal $\mathrm{C} 4 \mathrm{~d}$ positivity was found to be independently associated with the HCVTx- group $(p=0.016)$ and with periportal inflammation $(\mathrm{p}<0.001)$.

Quantification of HCV RNA in tissue - Tissue samples tested positive for HCV RNA in $6(21.4 \%)$ of the 28 RejHCV+ group cases, in $18(78.2 \%)$ of the $23 \mathrm{HCVTx}+$ group cases and in only one $(4 \%)$ of the 25 HCVTxgroup cases. In multiple comparisons, HCV RNA levels were higher in the HCVTx + group than in the RejHCV+ group $(\mathrm{p}<0.001)$ (Table IV).

Positivity for HCV RNA in tissue was found to correlate significantly with categorical and continuous variables: patient age (positive correlation, $r=0.297$, $\mathrm{p}=0.009$ ), time from transplantation to biopsy (positive correlation, $r=0.423, \mathrm{p}=0.002$ ) and portal fibrosis (negative correlation, $r=-0.440, \mathrm{p}=0.002$ ). In the multivariate analysis regression model, the independent factors for higher HCV RNA levels included the time from transplantation to biopsy and belonging to the $\mathrm{HCVTx}^{+}$ group ( $\mathrm{p}<0.001$ for both).

The ROC curve for the tissue level of HCV RNA presented an area under the curve of 0.818 (95\% confidence interval 0.695-0.942). Table $\mathrm{V}$ shows the sensitivity, specificity, positive predictive values and negative predictive values with a selected cut-off point of $58.15 \mathrm{IU} /$ $\mathrm{mL}$. According to the ROC curve data, in the presence of 


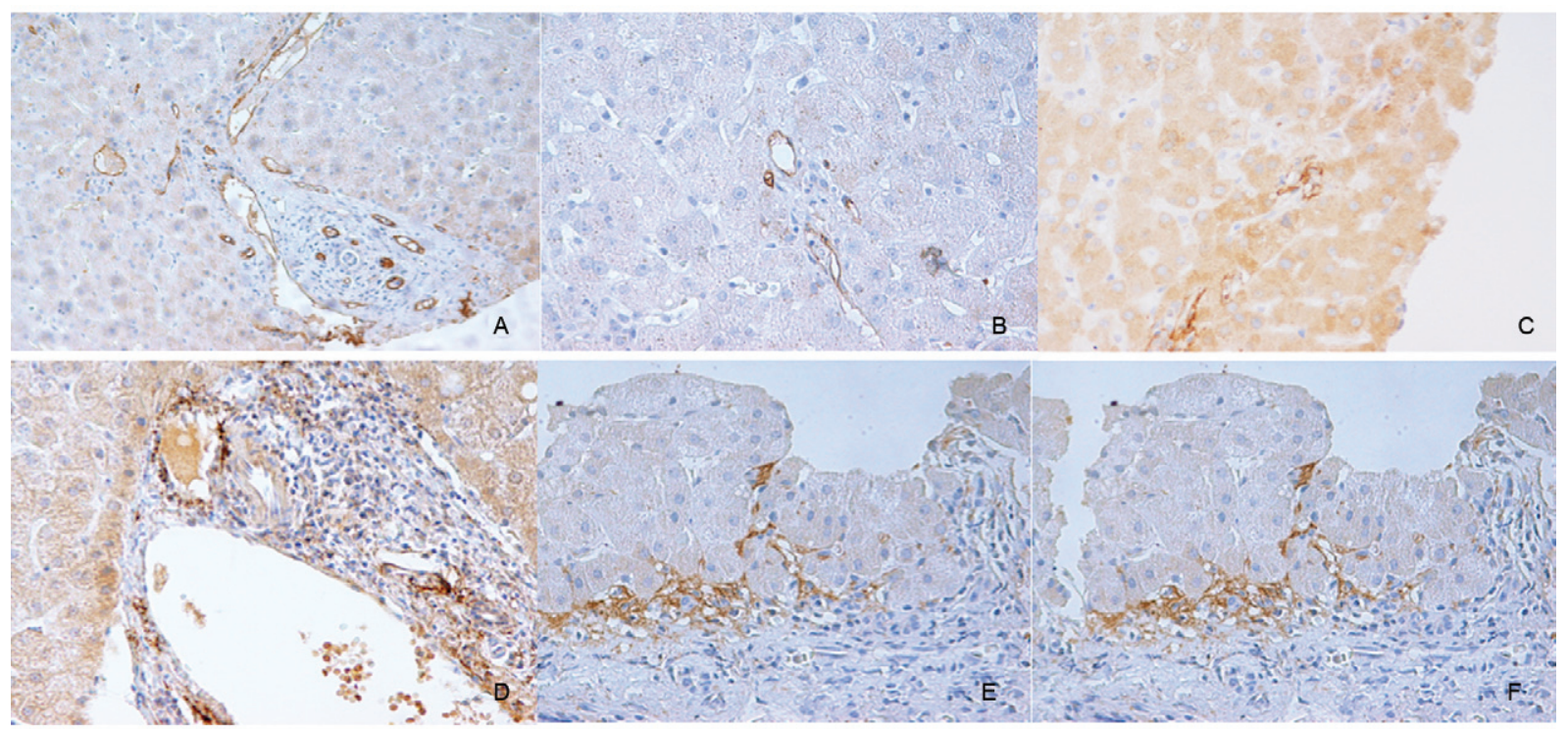

C4d immunostaining. A: acute rejection in patients undergoing liver transplant for hepatitis C (RejHCV+) group case with mild acute rejection (Banff 1/1/1) and strong C4d immunoreactivity in the endothelial cells of portal veins (400X); B: RejHCV+ group case with moderate acute rejection (Banff 2/2/2) and moderate C4d immunoreactivity in the endothelial cells of hepatic (centrilobular) vein (400X); $\mathrm{C}$ : acute rejection in patients undergoing liver transplant for reasons other than hepatitis C (RejHCV-) group case with severe acute rejection (Banff 3/3/3). Despite moderate background staining in hepatocytes, C4d immunoreactivity in the endothelial cells of hepatic (centrilobular) vein is quite evident (200X); D: chronic hepatitis C in patients in a non-transplant setting (HCVTx-) group case staged as representing Ishak grade 1 fibrosis and grade 2 periportal inflammation with C4d immunoreactivity in the endothelial cells of portal vein branches (400X); E: RejHCV- group case with severe acute rejection (Banff 2/2/3) presenting C4d immunoreactivity in endothelial cell membranes of pericentral sinusoids (400X); F: HCVTx- group case staged as representing Ishak grade 5 fibrosis and grade 0 periportal inflammation with $\mathrm{C} 4 \mathrm{~d}$ immunoreactivity in endothelial cell membranes of periseptal sinusoids (400X).

suggestive morphological lesions, the specificity of the quantitative PCR of HCV RNA for diagnosing hepatitis C recurrence was $100 \%$ for values higher than $1.410 \mathrm{IU} /$ $\mathrm{mL}$. We also found a statistically significant correlation between the tissue level and serum level of HCV RNA $(r$ $=0.391, \mathrm{p}=0.039$ ).

\section{DISCUSSION}

The differential diagnosis between acute rejection and hepatitis $\mathrm{C}$ recurrence is of great importance in the post-operative follow-up of liver transplant recipients (Burton Jr \& Rosen 2006). In the present study, there was no significant difference between the biopsy samples collected from the acute rejection patients and those collected from the hepatitis C-recurrent patients, in terms of the quantity of $\mathrm{C} 4 \mathrm{~d}$ deposition. However, the quantification of HCV RNA in tissue showed good accuracy for the diagnosis of hepatitis $\mathrm{C}$ recurrence.

Our findings corroborate those of Fayek (2012), who found that $\mathrm{C} 4 \mathrm{~d}$ staining was not able to differentiate between acute rejection and hepatitis $\mathrm{C}$ recurrence. However, previous studies, including one conducted by Schmeding et al. (2006), have suggested that C4d staining plays a major role in differentiating between acute rejection and hepatitis $C$ recurrence. In a subsequent study, Schmeding et al. (2010) used ELISA for C4d detection and did not identify any differences between the acute rejection and hepatitis C-recurrent groups in terms of the $\mathrm{C} 4 \mathrm{~d}$ levels. In both studies, the authors evaluated a small number of biopsies. However, other studies, which were also based on a small number of biopsies, have reported that $\mathrm{C} 4 \mathrm{~d}$ expression plays an important role in the differential diagnosis between acute rejection and hepatitis $\mathrm{C}$ recurrence (Jain et al. 2006, Lorho et al. 2006).

Differences between our patient groups, in terms of the demographic, clinical and laboratory data, do not appear to have affected our results. In the RejHCV+ and HCVTx+ groups, the recipient and donor ages were similar. Although the time from transplantation to biopsy was longer in the HCVTx + group patients, those patients required a definitive diagnosis and histological diagnosis that was considered to be the gold standard diagnostic method. Consequently, a diagnosis of acute rejection was more likely in the patients in whom the biopsies were performed within the first two months post-transplant, whereas a diagnosis of hepatitis $\mathrm{C}$ recurrence was more likely in the patients in whom the biopsies were performed more than six months post-transplant. Although we excluded the samples in which there were signs of both rejection and hepatitis $\mathrm{C}$ recurrence, such cases could be included in subsequent studies for validation purposes.

Considerable $\mathrm{C} 4 \mathrm{~d}$ deposition was observed in the HCVTx- group. In a non-transplant patient study conducted by Soglio et al. (2008), the biopsies tested positive for $\mathrm{C} 4 \mathrm{~d}$ in $40 \%$ of the chronic hepatitis C cases, $89 \%$ of the chronic hepatitis B cases and $83 \%$ of the autoimmune hepatitis cases. The authors suggested that $\mathrm{C} 4 \mathrm{~d}$ is not a useful marker for discriminating between acute rejection and hepatitis $\mathrm{C}$ recurrence. Other authors have observed C4d positivity in patients with chronic hepatitis B, autoimmune hepatitis or steatohepatitis, which calls into question the reliability of $\mathrm{C} 4 \mathrm{~d}$ as a marker of humoral rejection $(\mathrm{Bu}$ et al. 2006, Rensen et al. 2009, Aguilera et al. 2011). 
TABLE IV

Comparison of $\mathrm{C} 4 \mathrm{~d}$ deposition quantification and hepatitis $\mathrm{C}$ virus (HCV) RNA quantification in tissue by group

\begin{tabular}{|c|c|c|c|c|}
\hline Variable & Group & $\mathrm{n}$ & Mean (range) & $\mathrm{p}^{a}$ \\
\hline \multirow[t]{4}{*}{ Portal C4 $\mathrm{d}^{b}$} & RejHCV+ & 28 & $11.96(0-50)$ & \multirow[t]{4}{*}{0.002} \\
\hline & HCVTx + & 25 & $6.00(0-20)$ & \\
\hline & RejHCV- & 20 & $12.75(0-50)$ & \\
\hline & HCVTx- & 25 & $21.20(0-70)$ & \\
\hline \multirow[t]{4}{*}{ Centrilobular C4d } & RejHCV+ & 28 & $3.93(0-50)$ & \multirow[t]{4}{*}{0.052} \\
\hline & HCVTx + & 25 & 0.00 & \\
\hline & RejHCV- & 20 & $5.50(0-60)$ & \\
\hline & HCVTx- & 25 & $0.40(0-5)$ & \\
\hline \multirow[t]{4}{*}{ Sinusoidal C4d } & RejHCV+ & 28 & $0.54(0-5)$ & \multirow[t]{4}{*}{0.206} \\
\hline & HCVTx + & 25 & 0.00 & \\
\hline & RejHCV- & 20 & $0.50(0-10)$ & \\
\hline & HCVTx- & 25 & $0.80(0-5)$ & \\
\hline \multirow{3}{*}{$\begin{array}{l}\text { Tissue HCV RNA } \\
\text { (IU/mL) }\end{array}$} & RejHCV+ & 28 & $120.50(25-1.300)$ & \multirow{3}{*}{$<0.001$} \\
\hline & HCVTx + & 23 & $1610.46(25-15.900)$ & \\
\hline & RejHCV- & 25 & $26.50(25-62.4)$ & \\
\hline
\end{tabular}

$a$ : Kruskal-Wallis test; $b$ : no difference was found among groups acute rejection in patients undergoing liver transplant for hepatitis $\mathrm{C}(\mathrm{RejHCV}+)$, hepatitis $\mathrm{C}$ recurrence in patients undergoing liver transplant for hepatitis $\mathrm{C}\left(\mathrm{HCVTx}^{+}\right)$and acute rejection in patients undergoing liver transplant for reasons other than hepatitis C (RejHCV); HCVTx-: chronic hepatitis $\mathrm{C}$ in patients in a non-transplant setting.

During the pathogenesis of liver fibrosis, the innate and adaptive immune responses both play important roles (Hernandez-Gea \& Friedman 2011) and the complement system is known to be involved in the pathogenesis of chronic hepatitis C (Dunkelberger \& Song 2010). In a study assessing the mechanisms of cold activation of the complement system, Ishii et al. (2001) found that $\mathrm{C} 4 \mathrm{~d}$ deposition was greater in chronic hepatitis $\mathrm{C}$ patients than in $\mathrm{HCV}$-negative patients, suggesting that the classical and lectin pathways are both activated in the pathogenesis of hepatitis $\mathrm{C}$.

Although previous studies have demonstrated the involvement of the complement system in HCV-induced liver disease, such studies have detected the presence of other products of the complement pathway (Pham et al. 1995, Hillebrandt et al. 2005, Brown et al. 2010, Banerjee et al. 2011), such as the membrane attack complex, as well as interactions between the E1 and E2 HCV glycoproteins and between $\mathrm{C} 5$ and the $\mathrm{C} 5 \mathrm{a}$ receptor.

Given that the portal compartment demonstrated the greatest amount of $\mathrm{C} 4 \mathrm{~d}$ deposition, we performed a univariate analysis to identify the factors associated with C4d positivity in this compartment. The results indicated that portal immunostaining for $\mathrm{C} 4 \mathrm{~d}$ was associated with portal fibrosis, portal inflammation and
TABLE V

Accuracy of hepatitis $\mathrm{C}$ virus RNA quantification in tissue for diagnosing hepatitis $\mathrm{C}$ recurrence with a selected cut-off point of $58.15 \mathrm{IU} / \mathrm{mL}$

\begin{tabular}{lcc}
\hline Test characteristic & Performance & $95 \% \mathrm{CI}$ \\
\hline Accuracy & 0.80 & - \\
Sensitivity & 0.70 & $0.47-0.87$ \\
Specificity & 0.89 & $0.72-0.98$ \\
Positive predictive value & 0.84 & $0.60-0.97$ \\
Negative predictive value & 0.78 & $0.60-0.91$ \\
Positive likelihood ratio & 6.49 & $2.16-19.6$ \\
Negative likelihood ratio & 0.34 & $0.18-0.64$ \\
\hline
\end{tabular}

CI: confidence interval.

periportal inflammation. However, after observing that the advanced stages of fibrosis and inflammation were more common in the HCVTx- group, we performed multivariate analysis, which demonstrated that the only independent factors were periportal inflammation and belonging to the HCVTx- group. This result highlights a limitation of our study, namely that fibrosis and portal and periportal inflammation grading differed between the hepatitis groups (HCVTx+ and HCVTx-).

In a recent study (published after the present study was conducted), Kozlowski et al. (2012) advocated immunofluorescence staining of frozen sections as the most reliable method for assessing $\mathrm{C} 4 \mathrm{~d}$ deposition in liver allograft biopsies. In cases of kidney transplantation, immunofluorescence detection using monoclonal antibodies in frozen tissue demonstrated better detection performance than did the use of polyclonal antibodies and immunohistochemistry in paraffin-embedded tissue, with a loss of $\mathrm{C} 4 \mathrm{~d}$ positivity (from diffuse to focal and from focal to minimal or negative) in $30 \%$ of the cases (Seemayer et al. 2007). Additionally, a recent multicentre study employing the Banff $\mathrm{C} 4 \mathrm{~d}$ schema (Mengel et al. 2013) showed poor inter-institutional reproducibility of $\mathrm{C} 4 \mathrm{~d}$ staining with immunohistochemistry in paraffinised sections obtained from renal allograft biopsies, which was attributed to limitations in technique and a lack of inter-rater concordance.

There is also significant heterogeneity among studies regarding the descriptions of grading and the site of $\mathrm{C} 4 \mathrm{~d}$ deposition (Krukemeyer et al. 2004, Dankof et al. 2005, Sawada et al. 2005, Bu et al. 2006, Jain et al. 2006, Lorho et al. 2006, Schmeding et al. 2006, Sakashita et al. 2007, Aguilera et al. 2011, Kozlowski et al. 2011, Musat et al. 2011, Lunz et al. 2012). In general, it has been suggested that positivity should be defined only on the basis of the diffuse form of staining, which is commonly used to represent positivity in more than $50 \%$ of the compartments. In the majority of previous studies, grading has been performed semi-quantitatively. As there is no consensus on the recommendations for this marker in liver transplantation, we aimed to obtain a more precise result by selecting an estimated quantification of $\mathrm{C} 4 \mathrm{~d}$ expression in each 
compartment. Using quantitative grading, we also considered focal positivity and the statistical analysis was performed according to quantitative results.

In the present study, we found no difference between specimens showing acute rejection and those showing recurrence of hepatitis $\mathrm{C}$, in terms of $\mathrm{C} 4 \mathrm{~d}$ deposition, supporting the hypothesis that humoral mechanisms are involved in a small proportion of acute rejection episodes. However, those mechanisms also play a role in chronic hepatitis $\mathrm{C}$, which makes it difficult to discriminate between these two conditions using $\mathrm{C} 4 \mathrm{~d}$ as a tissue marker. The subject of humoral rejection in liver transplantation has been the object of many recent studies, as well as the subject of Banff Conferences since 2011, as no specific consensus criteria exist for this entity in this population (Mengel et al. 2012a, b). Most recent studies have evaluated $\mathrm{C} 4 \mathrm{~d}$ positivity and its correlation with a positive HLA crossmatch by detecting donor-specific antibodies (Aguilera et al. 2011, Bellamy 2011, Kozlowski et al. 2011, Musat et al. 2011, Lunz et al. 2012). In fact, this mechanism highlights another limitation of the current study, which is that we did not perform concomitant detection of donor-specific antibodies, which would have been informative, especially in cases of $\mathrm{C} 4 \mathrm{~d}$ positivity. It has been suggested that the characteristic histological features of antibodymediated rejection diffuse C $4 \mathrm{~d}$ positivity (present in $>$ $50 \%$ of portal tracts or sinusoids) and the presence of donor-specific antibodies (Hübscher 2012).

In the context of the available literature, our data indicate the need for prospective, controlled clinical follow-up studies further assessing the role of $\mathrm{C} 4 \mathrm{~d}$ expression in each hepatic compartment, in formalin-fixed and frozen samples. Such studies could lead to the development of a more comprehensive assessment of pre and post-transplant crossmatching, using C4d positivity to assess each histological abnormality. Since the 2011 Banff Conference (Mengel et al. 2012b), experts have been discussing this possibility.

We found that HCV RNA levels were higher in the HCVTx + samples than in the RejHCV+ samples, thus demonstrating good accuracy in predicting hepatitis $\mathrm{C}$ recurrence. These results corroborate those of previous studies, despite differences in the PCR techniques used (Aardema et al. 1999, Gottschlich et al. 2001, D'Errico-Grigioni et al. 2008). Because the time from transplantation to biopsy differed between the HCVTx + and RejHCV+ groups, subsequent studies involving the quantification of HCV RNA should use paired samples in order to validate the HCV RNA level as a discriminator of the two diagnoses. In addition, the complexity of the technique must be considered before its use in clinical practice can be defined.

The fact that we observed HCV RNA positivity in $21.4 \%$ of the RejHCV+ group cases implies that tissue re-infection precedes morphological lesions in cases of recurrence, as suggested by Guerrero et al. (1997) (Hübscher 2012). In the HCVTx- group, there was a high rate of undetectable HCV RNA, which might have been attributable to prolonged storage of the samples in formalin, because this group was evaluated in a non-transplant setting where the formalin fixation time varies from 8-24 $\mathrm{h}$, compared with $2 \mathrm{~h}$ in an urgent transplant setting. Additionally, previous studies have demonstrated lower rates of RNA detection, depending on the formalin fixation time (Guerrero et al. 1997). At the FMUSP Clinics Hospital, transplantation biopsy samples are processed within $2 \mathrm{~h}$, whereas other biopsy specimens are formalin-fixed for 8-24 h. Using quantitative PCR, we found a correlation between serum and tissue levels of $\mathrm{HCV}$ RNA, which is consistent with the findings of previous studies in transplant and non-transplant settings (Martín et al. 1998, Nuovo et al. 2002, Descamps et al. 2012).

In conclusion, the role of $\mathrm{C} 4 \mathrm{~d}$ positivity in liver transplantation and HCV-related hepatic disease has yet to be fully explained. However, the current study demonstrates that HCV RNA quantification in tissue is an accurate method of diagnosing hepatitis $\mathrm{C}$ recurrence.

\section{ACKNOWLEDGEMENTS}

To Alda Wakamatsu, for performing the C4d immunostaining, and to Rogerio Prado, for assisting in the statistical analysis.

\section{REFERENCES}

Aardema KL, Nakhleh RE, Terry LK, Burd EM, Ma CK, Moonka DK, Brown KA, Abouljoud MS 1999. Tissue quantification of hepatitis $\mathrm{C}$ virus RNA with morphologic correlation in the diagnosis of recurrent hepatitis $\mathrm{C}$ virus in human liver transplants. Mod Pathol 12: 1043-1049.

Aguilera I, Sousa JM, Gavilan F, Gomez L, Alvarez-Márquez A, Núñez-Roldán A 2011. Complement component 4d immunostaining in liver allografts of patients with de novo immune hepatitis. Liver Transpl 17: 779-788.

Banerjee A, Mazumdar B, Meyer K, Di Bisceglie AM, Ray RB, Ray $\mathrm{R} 2$ 2011. Transcriptional repression of $\mathrm{C} 4$ complement by hepatitis C virus proteins. J Virol 85: 4157-4166.

Banff schema for grading liver allograft rejection: an international consensus document 1997. Hepatology 25: 658-663.

Bellamy COC 2011. Complement C4d immunohistochemistry in the assessment of liver allograft biopsy samples: applications and pitfalls. Liver Transpl 17: 747-750.

Bellamy COC, Herriot MM, Harrison DJ, Bathgate AJ 2007. C4d immunopositivity is uncommon in ABO-compatible liver allografts, but correlates partially with lymphocytotoxic antibody status. Histopathology 50: 739-749.

Berenguer M 2002. Natural history of recurrent hepatitis C. Liver Transpl 8 (Suppl. 1): S14-S18.

Brown KS, Keogh MJ, Owsianka AM, Adair R, Patel AH, Arnold JN, Ball JK, Sim RB, Tarr AW, Hickling TP 2010. Specific interaction of hepatitis $\mathrm{C}$ virus glycoproteins with mannan binding lectin inhibits virus entry. Protein Cell 1: 664-674.

Bu X, Zheng Z, Yu Y, Zeng L, Jiang Y 2006. Significance of C4d deposition in the diagnosis of rejection after liver transplantation. Transplant Proc 38: 1418-1421.

Burton Jr JR, Rosen HR 2006. Acute rejection in HCV-infected liver transplant recipients: the great conundrum. Liver Transpl 12: S38-S47.

D’Errico-Grigioni A, Fiorentino M, Vasuri F, Gruppioni E, Fabbrizio B, Zucchini N, Ballardini G, Morelli C, Pinna AD, Grigioni WF 2008. Tissue hepatitis $C$ virus RNA quantification and protein expression help identify early hepatitis $\mathrm{C}$ virus recurrence after liver transplantation. Liver Transpl 14: 313-320. 
Dankof A, Schmeding M, Morawietz L, Günther R, Krukemeyer MG, Rudolph B, Koch M, Krenn V, Neumann U 2005. Portal capillary $\mathrm{C} 4 \mathrm{~d}$ deposits and increased infiltration by macrophages indicate humorally mediated mechanisms in acute cellular liver allograft rejection. Virchows Arch 447: 87-93.

Demetris AJ 2009. Evolution of hepatitis C virus in liver allografts. Liver Transpl 15 (Suppl. 2): S35-S41.

Descamps V, de Beeck AO, Plassart C, Brochot E, François C, Helle F, Adler M, Bourgeois N, Degré D, Duverlie G, Castelain S 2012. Strong correlation between liver and serum levels of hepatitis $\mathrm{C}$ virus core antigen and RNA in chronically infected patients. $J$ Clin Microbiol 50: 465-468.

Dunkelberger JR, Song W-C 2010. Complement and its role in innate and adaptive immune responses. Cell Res 20: 34-50.

Fayek SA 2012. The value of C4d deposit in post liver transplant liver biopsies. Transpl Immunol 27: 166-170.

Fragulidis GP, Cirocco RE, Weppler D, Berho M, Gillian G, Markou M, Viciana A, Esquenazi V, Nery JR, Miller J, Reddy KR, Tzakis AG 1998. In situ enzymatic oligonucleotide amplification of hepatitis C virus-RNA in liver biopsy specimens (reverse transcriptase in situ polymerase chain reaction) after orthotropic liver transplantation for hepatitis C-related liver disease. Transplantation 66: 1472-1476.

Gottschlich MJ, Aardema KL, Burd EM, Nakhleh RE, Brown KA, Abouljoud MS, Hirst K, Moonka DK 2001. The use of hepatitis $\mathrm{C}$ viral RNA levels in liver tissue to distinguish rejection from recurrent hepatitis C. Liver Transpl 7: 436-441.

Guerrero RB, Batts KP, Brandhagen DJ, Germer JJ, Perez RG, Persing DH 1997. Effects of formalin fixation and prolonged block storage on detection of hepatitis $\mathrm{C}$ virus RNA in liver tissue. $\mathrm{Di}$ agn Mol Pathol 6: 277-281.

Hernandez-Gea V, Friedman SL 2011. Pathogenesis of liver fibrosis. Annu Rev Pathol 6: 425-456.

Hillebrandt S, Wasmuth HE, Weiskirchen R, Hellerbrand C, Keppeler H, Werth A, Schirin-Sokhan R, Wilkens G, Geier A, Lorenzen J, Köhl J, Gressner AM, Matern S, Lammert F 2005. Complement factor 5 is a quantitative trait gene that modifies liver fibrogenesis in mice and humans. Nat Genet 37: 835-843.

Hübscher SG 2012. Antibody-mediated rejection in the liver allograft. Curr Opin Organ Transplant 17: 280-286.

Ishak K, Baptista A, Bianchi L, Callea F, de Groote J, Gudat F, Denk H, Desmet V, Korb G, MacSween RN 1995. Histological grading and staging of chronic hepatitis. J Hepatol 22: 696-699.

Ishii Y, Shimomura H, Itoh M, Miyake M, Ikeda F, Miyaike J, Fujioka S, Iwasaki Y, Tsuji H, Tsuji T 2001. Cold activation of serum complement in patients with chronic hepatitis C: study on activating pathway and involvement of IgG. Acta Med Okayama 55: 229-235.

Jain A, Ryan C, Mohanka R, Orloff M, Abt P, Romano J, Bryan L, Batzold P, Mantry P, Bozorgzadeh A 2006. Characterization of CD4, CD8, CD56 positive lymphocytes and C4d deposits to distinguish acute cellular rejection from recurrent hepatitis $\mathrm{C}$ in post-liver transplant biopsies. Clin Transpl 20: 624-633.

Kozlowski T, Andreoni K, Schmitz J, Hayashi PH, Nickeleit V 2012. Sinusoidal C4d deposits in liver allografts indicate an antibodymediated response: diagnostic considerations in the evaluation of liver allografts. Liver Transpl 18: 641-658.

Kozlowski T, Rubinas T, Nickeleit V, Woosley J, Schmitz J, Collins D, Hayashi P, Passannante A, Andreoni K 2011. Liver allograft antibody-mediated rejection with demonstration of sinusoidal $\mathrm{C} 4 \mathrm{~d}$ staining and circulating donor-specific antibodies. Liver Transpl 17: 357-368.
Krukemeyer MG, Moeller J, Morawietz L, Rudolph B, Neumann U, Theruvath T, Neuhaus P, Krenn V 2004. Description of B lymphocytes and plasma cells, complement and chemokines/receptors in acute liver allograft rejection. Transplantation 78: 65-70.

Leung JY, Abraczinskas DR, Bhan AK, Terella AM, Pascual M, Cosimi AB, Chung RT 2003. Recurrent allograft HCV presenting as acute cellular rejection: successful management with interferon and ribavirin alone. Clin Transplant 17: 275-283.

Lorho R, Turlin B, Aqodad N, Triki N, de Lajarte-Thirouard AS, Camus C, Lakehal M, Compagnon P, Dupont-Bierre E, Meunier B, Boudjema K, Messner M 2006. C4d: a marker for hepatic transplant rejection. Transplant Proc 38: 2333-2334.

Lunz J, Ruppert KM, Cajaiba MM, Isse K, Bentlejewski CA, Minervini M, Nalesnik MA, Randhawa P, Rubin E, Sasatomi E, de Vera ME, Fontes P, Humar A, Zeevi A, Demetris AJ 2012. Re-examination of the lymphocytotoxic crossmatch in liver transplantation: can C4d stains help in monitoring? Am J Transplant 12: 171-182.

Martín J, Navas S, Quiroga JA, Colucci G, Pardo M, Carreño V 1998. Quantitation of hepatitis $\mathrm{C}$ virus in liver and peripheral blood mononuclear cells from patients with chronic hepatitis $\mathrm{C}$ virus infection. J Med Virol 54: 265-270.

McCaughan GW, Zekry A 2002. Pathogenesis of hepatitis C virus recurrence in the liver allograft. Liver Transpl 8 (Suppl. 10B): S7-S13.

Mengel M, Chan S, Climenhaga J, Kushner YB, Regele H, Colvin RB, Randhawa P 2013. Banff initiative for quality assurance in transplantation (BIFQUIT): reproducibility of $\mathrm{C} 4 \mathrm{~d}$ immunohistochemistry in kidney allografts. Am J Transplant 13: 1235-1245.

Mengel M, Husain S, Hidalgo L, Sis B 2012a. Phenotypes of antibodymediated rejection in organ transplants. Transpl Int 25: 611-622.

Mengel M, Sis B, Haas M, Colvin RB, Halloran PF, Racusen LC, Solez K, Cendales L, Demetris AJ, Drachenberg CB, Farver CF, Rodriguez ER, Wallace WD, Glotz D, Banff meeting report writing committee 2012b. Banff 2011 Meeting report: new concepts in antibody-mediated rejection. Am J Transplant 12: 563-570.

Michaels PJ, Fishbein MC, Colvin RB 2003. Humoral rejection of human organ transplants. Springer Semin Immunopathol 25: 119-140.

Musat AI, Agni RM, Wai PY, Pirsch JD, Lorentzen DF, Powell A, Leverson GE, Bellingham JM, Fernandez LA, Foley DP, Mezrich JD, D'Alessandro AM, Lucey MR 2011. The significance of donor-specific HLA antibodies in rejection and ductopenia development in ABO compatible liver transplantation. Am J Transplant 11: 500-510.

Nuovo GJ, Holly A, Wakely Jr P, Frankel W 2002. Correlation of histology, viral load and in situ viral detection in hepatic biopsies from patients with liver transplants secondary to hepatitis $\mathrm{C}$ infection. Hum Pathol 33: 277-284.

Pham BN, Mosnier JF, Durand F, Scoazec JY, Chazouilleres O, Degos F, Belghiti J, Degott C, Benhamou JP, Erlinger S 1995. Immunostaining for membrane attack complex of complement is related to cell necrosis in fulminant and acute hepatitis. Gastroenterology 108: 495-504.

Regev A, Molina E, Moura R, Bejarano PA, Khaled A, Ruiz P, Arheart K, Berho M, Drachenberg CB, Mendez P, O'Brien C, Jeffers L, Tzakis A, Schiff ER 2004. Reliability of histopathologic assessment for the differentiation of recurrent hepatitis $\mathrm{C}$ from acute rejection after liver transplantation. Liver Transpl 10: 1233-1239.

Rensen SS, Slaats Y, Driessen A, Peutz-Kootstra CJ, Nijhuis J, Steffensen R, Greve JW, Buurman WA 2009. Activation of the complement system in human non-alcoholic fatty liver disease. Hepatology 50: 1809-1817.

Roche B, Samuel D 2007. Risk factors for hepatitis C recurrence after liver transplantation. J Viral Hepat 14 (Suppl. 1): 89-96. 
Saab S, Wang V 2003. Recurrent hepatitis C following liver transplant: diagnosis, natural history and therapeutic options. J Clin Gastroenterol 37: 155-163.

Sakashita H, Haga H, Ashihara E, Wen M-C, Tsuji H, MiyagawaHayashino A, Egawa H, Takada Y, Maekawa T, Uemoto S, Manabe T 2007. Significance of C4d staining in ABO-identical/ compatible liver transplantation. Mod Pathol 20: 676-684.

Sawada T, Shimizu A, Kubota K, Fuchinoue S, Teraoka S 2005. Lobular damage caused by cellular and humoral immunity in liver allograft rejection. Clin Transpl 19: 110-114.

Schmeding M, Dankof A, Krenn V, Krukemeyer MG, Koch M, Spinelli A, Langrehr JM, Neumann UP, Neuhaus P 2006. C4d in acute rejection after liver transplantation - a valuable tool in differential diagnosis to hepatitis C recurrence. Am J Transplant 6: 523-530.
Schmeding M, Kienlein S, Röcken C, Neuhaus R, Neuhaus P, Heidenhain C, Neumann UP 2010. ELISA-based detection of C4d after liver transplantation - a helpful tool for differential diagnosis between acute rejection and HCV-recurrence? Transpl Immunol 23: 156-160.

Seemayer CA, Gaspert A, Nickeleit V, Mihatsch MJ 2007. C4d staining of renal allograft biopsies: a comparative analysis of different staining techniques. Nephrol Dial Transplant 22: 568-576.

Soglio DB-D, Rougemont A-L, Herzog D, Soucy G, Alvarez F, Fournet J-C 2008. An immunohistochemical evaluation of C4d deposition in pediatric inflammatory liver diseases. Hum Pathol 39: 1103-1110.

Takakura K, Kiuchi T, Kasahara M, Inomata Y, Tanaka K 1999. Humoral immunity in acute cellular rejection after living-donor liver transplantation. Transplant Proc 31: 526-527. 